\title{
The Profile and Significance of Listed Property Companies in Some Selected African Countries
}

\author{
Sadiq Tukur ${ }^{1}$, Jamilu Shehu ${ }^{1}$ \\ ${ }^{1}$ Abubakar Tafawa Balewa University \\ Tawafa Belewa Way, P. M. B. 0248, Bauchi, 740272, Nigeria
}

DOl: $10.22178 /$ pos. $45-1$

JEL Classification: R11

Received 26.03.2019

Accepted 27.04.2019

Published online 30.04.2019

Corresponding Author:

Sadiq Tukur

modybbo@yahoo.com

(C) 2019 The Authors. This article

is licensed under a Creative Commons

Attribution 4.0 License @) (1)

\begin{abstract}
This study investigates the significance and profile of Listed Property Companies (LPCs) in 10 African countries namely; Botswana, Egypt, Kenya, Mauritius, Morocco, Nigeria, South Africa, Tunisia, Zambia, and Zimbabwe respectively for the period of 10 years from 2006 to 2015., the profile and some key indicators of each respective country has been identified to determine the significance of each respective economy. The study uses secondary data obtained from Thompson Reuters DataStream to extract the number of companies in each country and their respective profiles. Descriptive statistics were used to analyze 64 Listed Property Companies using simple percentages. The study revealed that most of the African countries are Opaque with very few semi-transparent such as Kenya, Mauritius, and Botswana with the exception of South Africa which is the only transparent, the study further revealed that most of the companies are established between 2010 to 2015. Egypt has the highest number of property companies 29 represented by $45.31 \%$ followed by South Africa with 16 Listed property Companies Represented by $25 \%$ while Nigeria, Kenya and Zambia have the least number of companies with 1 each represented by $1.56 \%$.
\end{abstract}

Keywords: Africa; profile; listed property companies; market value.

\section{INTRODUCTION}

The significant increase of real estate securities in financial investment markets made real estate in Africa to continue receiving widespread attention and interest from both corporate bodies and the general public as one of the favorable and consistent opportunities, both the direct and indirect property investment has been regarded as an alternative way of investing in real estate. The acquisition of shares in property investment companies specializing in real estate activities has become a more popular investment in indirect property. Generally, the two fundamental investment decisions attributes are a risk and return. The process, in theory, could be limited to finding an investment option with the best riskreturn ratio, uncertainties and risks are the most common features and characteristics of every form of investment not only property investment, and the only way to manage them is by combining the assets, which would yield better returns in a portfolio.

Africa is considered as an attractive expansion destination for investors due to the global mega- trend such as rapid urbanization and demographic changes. Moreover, Real estate is becoming a driving factor influencing the changing face of entire cities and markets across the continent. Within this context, real estate is increasingly seen not only as a facilitator of business investment and economy but also as a potential source for a competitive advantage [17]. Real estate, according to [20], serves as an effective means of diversifying risk in a mixed-asset portfolio as a result of its long term strategic performance. Despite all of the above, direct investment in real estate is subject to some difficulties, it has for example been traditionally regarded as an investment that is involving so many funds to acquire and illiquid. Moreover, for an ordinary private investor, a direct property acquisition may be difficult as a result of the large amounts of capital needed, as well as the high cost of a transaction. An option for avoiding these difficulties may be the acquisition of shares in investment companies who are specialized in real estate investment. Real estate securitization has been therefore identified as the logical answer to the efficient demand for real estate diversified portfolio. 
It provides the investors high liquidity advantage, with an indirect means by which small investors could invest in property and enjoy the economic benefits.

Listed property companies are companies that own income-producing properties for investment purposes, this entails investing in a portfolio of commercial property assets comprising of, residential commercial, retail, and warehouse which is managed by a specialist property fund manager. The listed property sector reveals information about the changes in property values in a timely manner as opposed to the periodic reports that are compiled either monthly or quarterly [10]. Investors receive a share of the rental income collected from the property depending on the number of shares an investor has in the short term and they will benefit from any capital gain that is realized in the long term. Price fluctuations observed in property investments are often attributable to the changes in property fundamentals [10]. Authors [10] conclude that the stock market provides reliable measures of return for the property market which is considered to be one of the most important asset classes and yet not much research has been done on this subject.

Property companies are one of the major players in the real estate market. Listed property companies are normally engaged with business activities such as real estate development, investment and trading with a diverse portfolio of investment such as residential, commercial property and trading. Listed property companies provide an investment tool for investors to invest in real estate indirectly. Shares in listed property companies allow people to buy real estate ln piecemeal. Shares in these companies are just the same as other stock markets which are highly liquid and are allowed to be traded many times on a daily basis. This contrasts with investment in property trading which takes several months to complete a transaction. This indirect property investment should reflect the performance underlying real estate in certain countries itself. The value of listed property companies relies on company shares which gain from the relationship to the value of the real estate it owns and the income from business operations. In the capitalist system, the value will fluctuate depending on the economic situation and value of real estate owned. Investors are no longer considering property as a single investment and are instead including property investment with other asset classes. Property investment has to compete against these other classes, primarily equities and bonds. Expected return, risk, and diversification are all important in determining the allocation to these assets.

Previous studies on the significance of the property in mixed-asset portfolios concentrated only on certain countries such as Singapore, Japan, Malaysia, Hong Kong, Australia, the US, and the UK. There is a lack of in-depth empirical research conducted specifically on the African property market; especially on listed property companies. The reason may be due to a lack of data which is related to the property industry. The data concerning the real estate market in African countries has been extremely limited, resulting in a lack of sufficient information regarding real estate assets in many investment portfolios in Africa.

Africa's Property market has traditionally lagged behind many emerging and developed economies in the world. The various levels of property investment in Africa are low compared to global standards and there exist a significant potential opportunity to explore by investors. The African property market is in a good positioned to harness an increasing growth prospect, with over 400 million urbanized populations, constituting about $40 \%$ of the total population in the continent. The African property market is rapidly growing and attracting more interest from international investor's occupiers and developers from different part of the world. RICS is proceeding with its expansion in Africa which as a result will allow property sectors to attain international standards.

Investors are widening and expanding their activities across a wider range of geographical locations, driving development in infrastructure and thereby supporting economic growth. Improvements in property development, alongside wider improvements in the business operating environment, can be important accelerators in achieving greater international investment and fast-tracking economic growth. As mature economies continue to face economic challenges and stagnating economies, more investors are considering expanding into Africa to benefit from its high growth potential. This is resulting in a growing demand for real estate, corporate business infrastructure, and the consequent development of the commercial real estate sector. However, there is lack of extensive research carried out in the past covering any of the African countries apart from few countries such as Nige- 
ria and South Africa which brings limited literature on the performance of property listed companies over the past years. The performance of property securities in most of the African countries have not been analyzed due to its infancy stage, problems of access to data, lack of awareness and expertise in countries, particularly on property investment. In order to determine whether property investment has performed well or not, it requires measuring performance so that management of investment and related decisions can be determined on a regular basis.
The limited flow of foreign investment into the property markets in Africa generally, has been attributed in part to lack of investors' confidence, resulting from a low level of research activities and limited information (Lim et al., 2006). The markets are therefore perceived as too risky by international investors. To sustain and increase the flow of investment capital into the real estate securities in the African countries requires research to be carried out on the significance of the property sector from time to time which will reveal the performance of the listed property companies and attract foreign investors (Tables 1, 2).

Table 1 - Key Economic Indicators

\begin{tabular}{|l|c|c|c|c|c|c|c|c|}
\hline Country & $\begin{array}{c}\text { Population } \\
\text { rate 2015, } \\
\text { million }\end{array}$ & $\begin{array}{c}\text { GDP } \\
2015, \\
\$ \text { Billion }\end{array}$ & $\begin{array}{c}\text { Unemployment } \\
\text { Rate 2015 }\end{array}$ & $\begin{array}{c}\text { Inflation } \\
\text { Rate, } \%\end{array}$ & $\begin{array}{c}\text { Corruption } \\
\text { perception } \\
\text { index 2014 }\end{array}$ & $\begin{array}{c}\text { Global } \\
\text { Competitiveness } \\
\text { index 2014 }\end{array}$ & $\begin{array}{c}\text { Risk } \\
\text { Rating } \\
\text { E= } \\
\text { Most } \\
\text { Risky) }\end{array}$ & $\begin{array}{c}\text { World } \\
\text { bank doing } \\
\text { business } \\
(189) \\
2015\end{array}$ \\
\hline Botswana & 2.2 & 15.2 & 17.8 & 3.9 & 28 & 74 & B & 174 \\
\hline Egypt & 88 & 286.4 & 8.1 & 10.1 & 88 & 119 & $\mathrm{C}$ & 112 \\
\hline Kenya & 45 & 60.9 & 42 & 6.9 & 139 & 90 & $\mathrm{C}$ & 136 \\
\hline Mauritius & 1.3 & 12.6 & 7.9 & 3.2 & 45 & 39 & $\mathrm{~B}$ & 28 \\
\hline Morocco & 33 & 110.0 & 5.5 & 0.4 & 88 & 72 & $\mathrm{C}$ & 74 \\
\hline Nigeria & 177.2 & 570.4 & 6.4 & 8.1 & 136 & 127 & $\mathrm{D}$ & 170 \\
\hline S/Africa & 54 & 350.1 & 24.3 & 6.1 & 61 & 56 & $\mathrm{C}$ & 43 \\
\hline Tunisia & 10.9 & 26.6 & 15.2 & 4.9 & 76 & 87 & $\mathrm{C}$ & 60 \\
\hline Zambia & 14.6 & 13.8 & 15 & 7.8 & 76 & 96 & $\mathrm{C}$ & 111 \\
\hline Zimbabwe & 12.6 & 13.6 & 70 & 0.1 & 150 & 124 & $\mathrm{D}$ & 171 \\
\hline
\end{tabular}

Source: $[8,12,22,23]$.

Table 2 - Global Real Estate Transparency Index (African countries)

\begin{tabular}{|c|c|c|c|c|c|c|c|}
\hline \multirow{2}{*}{ Transparency } & \multirow{2}{*}{ Country } & \multicolumn{2}{|c|}{2014} & \multicolumn{2}{|c|}{2012} & \multirow{2}{*}{ Difference } & \multirow{2}{*}{ Score } \\
\hline & & Rank & Score & Rank & Score & & \\
\hline Semi-Transparent & South Africa & 20 & 2.09 & 21 & 2.18 & +1 & -0.09 \\
\hline \multirow[t]{3}{*}{ Semi-Transparent } & Kenya & 48 & 3.09 & 65 & 3.70 & +17 & -0.09 \\
\hline & Mauritius & 51 & 3.14 & 59 & 3.43 & +8 & -0.29 \\
\hline & Botswana & 55 & 3.29 & 56 & 3.36 & +1 & -0.07 \\
\hline \multirow[t]{4}{*}{ Low Transparent } & Egypt & 63 & 3.49 & 77 & 3.88 & +14 & -0.39 \\
\hline & Morocco & 72 & 3.67 & 76 & 3.88 & +4 & -0.21 \\
\hline & Zambia & 76 & 3.76 & 78 & 3.93 & +2 & -0.17 \\
\hline & Uganda & 82 & 3.97 & - & - & - & - \\
\hline \multirow[t]{9}{*}{ Opaque } & Angola & 83 & 3.98 & 95 & 4.58 & +12 & -0.6 \\
\hline & Ethiopia & 86 & 4.03 & - & - & - & - \\
\hline & Mozambique & 88 & 4.20 & - & - & - & - \\
\hline & Senegal & 90 & 4.20 & - & - & - & - \\
\hline & Libya & 92 & 4.23 & - & - & - & - \\
\hline & Ghana & 95 & 4.36 & 90 & 4.41 & -5 & -0.05 \\
\hline & Algeria & 98 & 4.46 & 93 & 4.49 & -5 & -0.03 \\
\hline & Nigeria & 101 & 4.52 & 96 & 4.58 & -5 & -0.06 \\
\hline & Tunisia & 102 & 4.63 & 89 & 4.38 & +13 & +0.25 \\
\hline Not Covered & Zimbabwe & - & - & - & - & - & - \\
\hline
\end{tabular}

Source: [13]. 
Tables 2 shows the real estate transparency index and ranking of African countries 2012-2014, with South Africa being the only transparent market among the number of countries, South African property market has been the most performing market of real estate in Africa. Botswana, Kenya, and Mauritius are the semi-transparent market, Egypt, Morocco, Zambia, and Uganda are the low transparent real estate markets while most of the countries from Africa are Opaque, these include Angola, Ethiopia, Mozambique, Senegal, Libya, Ghana, Algeria Nigeria, and Tunisia. However, Zambia is not covered in the transparency index of 2012 as well as in 2014. The real estate transparency ranking of the African countries 2014 shows that South Africa is at the extreme top and is being ranked \#20 followed by Kenya 48, Mauritius \#51 and Botswana \#55. Countries in the middle of the ranking include Egypt \#63 and Morocco \#72. Countries at the bottom of the ranking are Nigeria \#86, Zambia \#92 and Zimbabwe \#192 respectively.

\section{MATERIALS AND METHODS}

Data concerning Listed Property Companies from 10 African Countries (Botswana, Egypt, Kenya, Mauritius, Morocco, Nigeria, South Africa, Tunisia, Zambia, and Zimbabwe) covering 10 years from January 2006 to December 2015 was obtained from Thompson Reuters DataStream to analyze the significance and profile of Listed Property Companies in Africa. The profile and some key indicators of each respective country were identified to determine the significance of each respective economy. The quantitative data were analyzed using descriptive statistics, simple percentages are used in analyzing the data obtained (Table 3).

Table 3 - Listed property Companies, Date Listed and Market Value

\begin{tabular}{|l|l|r|r|}
\hline No & Country / Companies & \multicolumn{1}{c|}{$\begin{array}{c}\text { Date } \\
\text { Listed }\end{array}$} & $\begin{array}{c}\text { Market Value, } \\
\$ \text { Mln }\end{array}$ \\
\hline \multicolumn{3}{|c|}{ Botswana Listed Property Companies } \\
\hline 1 & $\begin{array}{l}\text { Primetime Prp } \\
\text { Holding }\end{array}$ & 2007 & 49.43 \\
\hline 2 & RDC Properties & 2011 & 49.08 \\
\hline 3 & Turnstar Holdings & 2002 & 125.78 \\
\hline 4 & $\begin{array}{l}\text { New African } \\
\text { Properties }\end{array}$ & 1996 & 136.01 \\
\hline \multicolumn{3}{|c|}{ Egypt Listed Property Companies } \\
\hline 1 & Egyptian Rlst. Consort & 2005 & 0.85 \\
\hline
\end{tabular}

\begin{tabular}{|c|c|c|c|}
\hline No & Country / Companies & $\begin{array}{c}\text { Date } \\
\text { Listed }\end{array}$ & $\begin{array}{l}\text { Market Value, } \\
\text { \$ Mln }\end{array}$ \\
\hline 2 & Arab Rlst. Inv. (Alco) & 2011 & 21.4 \\
\hline 3 & $\begin{array}{l}\text { Cairo Development } \\
\text { Inv. }\end{array}$ & 1992 & 22.9 \\
\hline 4 & \begin{tabular}{|l|} 
Delta Con. \& \\
Rebuilding \\
\end{tabular} & 1992 & 23.4 \\
\hline 5 & Golden Pyramid Plaza & 1997 & 783.9 \\
\hline 6 & $\begin{array}{l}\text { National HSE. Prof. } \\
\text { Synd. }\end{array}$ & 1995 & 16.5 \\
\hline 7 & $\begin{array}{l}\text { Rowad Tourism (Al } \\
\text { Rowad) }\end{array}$ & 1995 & 81.3 \\
\hline 8 & $\begin{array}{l}\text { Zahraa Maadi Inv. \& } \\
\text { Dev. }\end{array}$ & 1996 & 103.2 \\
\hline 9 & Gulf Canadian Rlst. & 2011 & 5.4 \\
\hline 10 & $\begin{array}{l}\text { National Rlst. Bank } \\
\text { Dev. }\end{array}$ & 1992 & 5.3 \\
\hline 11 & Araba Land Reclaim & 1996 & 3.95 \\
\hline 12 & $\begin{array}{l}\text { Obour Rlst. } \\
\text { Investment }\end{array}$ & 1998 & 2.57 \\
\hline 13 & $\begin{array}{l}\text { Egypt Brit National } \\
\text { Dev }\end{array}$ & 1999 & 234.34 \\
\hline 14 & $\begin{array}{l}\text { Taalat Moustafa } \\
\text { Group }\end{array}$ & 2007 & 2956.04 \\
\hline 15 & Palm Hills Devs. Sae & 2006 & 715.68 \\
\hline 16 & Development \& Engr. & 1996 & 24.78 \\
\hline 17 & $\begin{array}{l}\text { Mena Tourism \& Rlst. } \\
\text { Inv. }\end{array}$ & 1995 & 16.71 \\
\hline 18 & $\begin{array}{l}\text { Six of October Dev. \& } \\
\text { Inv. }\end{array}$ & 1998 & 609.85 \\
\hline 19 & $\begin{array}{l}\text { Egyptians Housing } \\
\text { Dev. }\end{array}$ & 1994 & 72.83 \\
\hline 20 & Egyptians Inv. \& URD. & 2011 & 16.15 \\
\hline 21 & $\begin{array}{l}\text { Ismailia Dev. \& RLST. } \\
\text { REIT }\end{array}$ & 2011 & 28.2 \\
\hline 22 & \begin{tabular}{|l} 
North Africa Real \\
Estate
\end{tabular} & 2012 & 45.73 \\
\hline 23 & $\begin{array}{l}\text { United Housing \& } \\
\text { Dev. }\end{array}$ & 1994 & 172.52 \\
\hline 24 & $\begin{array}{l}\text { El-Kahera Housing \& } \\
\text { Dev }\end{array}$ & 1995 & 115.99 \\
\hline 25 & Holiopolis Housing & 1995 & 934.23 \\
\hline 26 & Medinet Nasr Housing & 1995 & 909.96 \\
\hline 27 & $\begin{array}{l}\text { Arab Dev. \& Real } \\
\text { Estate }\end{array}$ & 2011 & 21.40 \\
\hline 28 & $\begin{array}{l}\text { Misr Elsalam Dev. \& } \\
\text { Tech }\end{array}$ & 2015 & 13.11 \\
\hline 29 & Emaar Misr for Dev. & 2015 & $1,303.79$ \\
\hline \multicolumn{4}{|c|}{ Kenyan Listed Property Companies } \\
\hline 1 & \begin{tabular}{|l|} 
Home Africa \\
\end{tabular} & 2013 & 16.38 \\
\hline \multicolumn{4}{|c|}{ Mauritius Listed Property Companies } \\
\hline 1 & \begin{tabular}{|l|l|} 
Covifra \\
\end{tabular} & 1972 & 12.35 \\
\hline 2 & Rockcastle Glre. & 2012 & $1,831.89$ \\
\hline 3 & \begin{tabular}{|l|} 
New Frontier \\
Properties
\end{tabular} & 2014 & 1.55 \\
\hline \multicolumn{4}{|c|}{ Morocco Listed Property Companies } \\
\hline 1 & \begin{tabular}{|l|l|} 
Balima & \\
\end{tabular} & 1946 & 20.82 \\
\hline 2 & Douja Prom Addoha & 2006 & $1,066.43$ \\
\hline
\end{tabular}




\begin{tabular}{|l|l|r|r|}
\hline No & Country / Companies & $\begin{array}{c}\text { Date } \\
\text { Listed }\end{array}$ & \multicolumn{1}{c|}{$\begin{array}{c}\text { Market Value } \\
\text { \$ Mln }\end{array}$} \\
\hline 3 & $\begin{array}{l}\text { Alnc. Dvppt. } \\
\text { Immobilier }\end{array}$ & 2010 & 174.77 \\
\hline 4 & Res Dar Saada & 2014 & 456.91 \\
\hline \multicolumn{3}{|c|}{ Nigeria Listed Property Companies } \\
\hline 1 & UACN Property Dev. & 1997 & \multicolumn{1}{|c|}{84.67} \\
\hline \multicolumn{3}{|l|}{ South Africa Listed Property Companies } \\
\hline 1 & $\begin{array}{l}\text { Ingenuity Property } \\
\text { Invs. }\end{array}$ & 2000 & 96.83 \\
\hline 2 & Tradehold & 1970 & 252.29 \\
\hline 3 & $\begin{array}{l}\text { Quantum Property } \\
\text { Group }\end{array}$ & 1984 & 2.53 \\
\hline 4 & Putprop & 1988 & 24.26 \\
\hline 5 & Orion Real Estate & 1991 & 15.34 \\
\hline 6 & $\begin{array}{l}\text { Adrenna Property } \\
\text { Group }\end{array}$ & 1998 & 3.40 \\
\hline 7 & $\begin{array}{l}\text { Delta Africa Prop } \\
\text { Holdings }\end{array}$ & 2002 & 83.37 \\
\hline 8 & Bonatla Pr. & 1996 & 3.09 \\
\hline 9 & Visual International & 2006 & 5.8 \\
\hline 10 & Freedom & 2014 & 33.9 \\
\hline 11 & Attacq Ord & 1994 & $1,503.17$ \\
\hline 12 & The Pivotal Fund & 2005 & 477.88 \\
\hline 13 & Acsion Limited & 2006 & 371.88 \\
\hline 14 & Stenprop & 2015 & 460.63 \\
\hline 15 & Renergen Limited & 2015 & 2361 \\
\hline 16 & Balwin Properties & 1996 & 2546 \\
\hline & \multicolumn{2}{|c|}{ Tunisia Listed Property Companies } \\
\hline 1 & Simpar & 1996 & 28.46 \\
\hline 2 & $\begin{array}{l}\text { Sc. Immob. Tunis- } \\
\text { Seoudien }\end{array}$ & 1997 & 14.53 \\
\hline 3 & Essoukna & 2006 & 15.03 \\
\hline & \multicolumn{2}{|c|}{ Zambia listed Property Companies } \\
\hline 1 & $\begin{array}{l}\text { Real Estate } \\
\text { Investment BIA. }\end{array}$ & 1996 & 32.45 \\
\hline \multicolumn{2}{|l|}{ Zimbabwe Listed Property Companies } \\
\hline 1 & Dawn Properties & 2003 & 24.57 \\
\hline 2 & $\begin{array}{l}\text { Pearl Properties } \\
\text { (2006) }\end{array}$ & 2007 & 34.67 \\
\hline
\end{tabular}

Table 4 - Year Company Listed on Stock Exchange

\begin{tabular}{|l|c|c|}
\hline \multicolumn{1}{|c|}{ Year } & $\begin{array}{c}\text { Number of } \\
\text { companies }\end{array}$ & $\begin{array}{c}\text { Percentage } \\
\%\end{array}$ \\
\hline $\begin{array}{l}1986 \text { and } \\
\text { before }\end{array}$ & 3 & 4.69 \\
\hline $1991-1995$ & 13 & 20.31 \\
\hline $1996-2000$ & 16 & 25.00 \\
\hline $2001-2005$ & 6 & 9.38 \\
\hline $2006-2010$ & 9 & 14.06 \\
\hline $2011-2015$ & 17 & 26.56 \\
\hline
\end{tabular}

1986 and before was the years with least number of listed companies recording only 3 represented by $4.69 \%$ and 2001 to 2005 with 6 companies represented by $9.38 \%$ respectively.

Table 5 - Country LPCs and their respective Market Value

\begin{tabular}{|l|r|r|r|r|}
\hline Country & $\begin{array}{c}\text { No of } \\
\text { Companies }\end{array}$ & $\begin{array}{c}\text { \% of } \\
\text { companies }\end{array}$ & $\begin{array}{c}\text { Market } \\
\text { Value, } \\
\$ \text { mln }\end{array}$ & $\begin{array}{c}\text { \% of } \\
\text { Market } \\
\text { value }\end{array}$ \\
\hline Botswana & 4 & 6.25 & 360.3 & 1.66 \\
\hline Egypt & 29 & 45.31 & 9233.69 & 42.65 \\
\hline Kenya & 1 & 1.56 & 16.38 & 0.08 \\
\hline Mauritius & 3 & 4.69 & 1845.79 & 8.53 \\
\hline Morocco & 4 & 6.25 & 1718.93 & 7.94 \\
\hline Nigeria & 1 & 1.56 & 84.67 & 0.39 \\
\hline South & 16 & 25.00 & 8241.37 & 38.06 \\
Africa & 3 & 4.69 & 58.02 & 0.27 \\
\hline Tunisia & 1 & 1.56 & 32.45 & 0.15 \\
\hline Zambia & 2 & 3.13 & 59.24 & 0.27 \\
\hline Zimbabwe & 64 & 100 & 21650.8 & 100 \\
\hline Total & & & & \\
\hline
\end{tabular}

Table 5 above highlights the number of companies in each respective country, Egypt has the highest number of companies with 29 companies represented by $45.31 \%$ with a market value of $\$$ 9,233.69 million (42.65\%), followed by South Africa with 16 companies with $25 \%$ with a total market value of $\$ 8241.37$ million (38.06\%). Kenya, Nigeria, and Zambia have the least number of company with 1 each represented by $1.56 \%$ and a market value of $\$ 16.38$ million (0.08\%), \$84.67 (0.39) and \$32.45 (0.15).

Table 4 above highlights the range of years and corresponding percentages which countries were listed on Various Stock Exchange of each respective country. The highest number of companies of up to 17 represented by $26.56 \%$ were listed between the years of 2011 to 2015 followed by 1996 to 2000 which also recorded 16 companies $25 \%$ respectively.

\section{CONCLUSION}

The study investigates on the Significance and profile of Listed Property Companies in some selected African countries. The study also developed a profile of African listed property companies obtained from DataStream. The study explored the number of listed property companies 
in each country, the date listed on the stock exchange and its market value in USD. Egypt has the highest number of companies followed by South Africa. The year 2011 to 2015 has witnessed the highest number of Property Companies listed on the stock exchange while 1986 and before has the least number of companies listed on the various stock exchange. This clearly shows that more companies are listed in recent years

This information will help the investors to know well and study about each company they are investing their money into, as investors don't in- vest blindly into the market but need convincing evidence in reality. The government of the African countries should make Data on property stocks and broader stock market available and accessible in African universities and institutions by subscribing to Thompson Reuters data stream and other sources of readily available data on stock indices which will facilitate and promote research to be carried out from time to time basis, thereby helping stakeholders and investors in directing their capital sum for investment without any fear of losing their money.

\section{REFERENCES}

1. Abdullah, N., \& Wan Zahari, W. (2011). Performance of Property Listed Companies in Malaysia: 1996-2007. In Global Business and Social Sciences Research Conference, 20-21 June 2011. Retrieved from http://repo.uum.edu.my/3721

2. Abdul-Rasheed, A., \& Tajudeen, A. (2006). Performance Analysis of Listed Construction and Real Estate Companies in Nigeria. Journal of Real Estate Portfolio Management, 12(2), 177-85.

3. Astill, J. (2015, January 8). The twilight of the resource curse? The Economist. Retrieved from https://www.economist.com/middle-east-and-africa/2015/01/08/the-twilight-of-theresource-curse

4. Baum, A. (2008). The emergence of real estate funds. In A. Peterson (Ed.), Real Estate Finance: Law, Regulation and Practice (pp. 145-178). London: LexisNexis.

5. Central Intelligence Agency. (2012). World Factbook 2012. Retrieved from https://www.cia.gov/library/publications/download/download-2012/index.html

6. Central Intelligence Agency. (2015). World Factbook 2015. Retrieved from https://www.cia.gov/library/publications/download/download-2015/index.html

7. Chong, S. W., Geh, J. W., Tan, Q. S., Tey, C. K., \& Yap, K. T. (2014). The risk-adjusted performance of Malaysia listed property companies: a comparative analysis (Doctoral thesis). Retrieved from http://eprints.utar.edu.my/1443/1/FBF-2014-1201324.pdf

8. Economist Intelligent Unit. (2019). Country Forecast. Retrieved March 1, 2019, from https://store.eiu.com/product/country-forecast

9. Emele, C. R., \& Umeh, O. L. (2013). A fresh look at the performance and diversification benefits of real estate equities in Nigeria: Case study of real estate equity and some selected common stocks. International Journal of Development and Sustainability, 2(2), 1300-1311.

10. Gyourko, J., \& Keim, D. B. (1993). Risk and Return in Real Estate: Evidence from a Real Estate Stock Index. Financial Analysts Journal, 49(5), 39-46. doi: 10.2469/faj.v49.n5.39

11. Hwa, J. K. (2002, January). Listed Property Companies in Malaysia: A Comparative Performance Analysis. Retrieved from http://citeseerx.ist.psu.edu/viewdoc/download;jsessionid=9F2FEB674F23B48D5C12A0EB21C C7708?doi=10.1.1.195.1308\&rep=rep1\&type $=$ pdf

12. International Bank. (2014). Doing Business 2015. Retrieved from http://www.doingbusiness.org/content/dam/doingBusiness/media/AnnualReports/English/DB15-Full-Report.pdf

13. Jones Lang LaSalle. (2019). Transparency: Data, Disclosure \& Disruption. Retrieved from http://greti.jll.com/greti/transparency-Compared 
14. Kim Nguyen, T. (2010). The Significance and Performance of Listed Property Companies in Vietnam. Pacific Rim Property Research Journal, 16(2), 221-245. doi: 10.1080/14445921.2010.11104303

15. Kim Nguyen, T. (2011). The Significance and Performance of Listed Property Companies in Asian Developed and Emerging Markets. Pacific Rim Property Research Journal, 17(1), 24-47. doi: 10.1080/14445921.2011.11104316

16. Kim Nguyen, T. (2011). The Significance and Performance of Listed Property Companies in the Philippines. Pacific Rim Property Research Journal, 17(2), 260-286. doi: 10.1080/14445921.2011.11104328

17. Knight Frank. (2015). Real Estate Markets in a Continent of Growth and Opportunity. African Report 2015. Retrieved from https://www.africanbusinesscentral.com/wpcontent/uploads/2015/08/Africa-Report-2015-Real-Estate-Markets-in-a-Continent-of-Growthand-Opportunity-Knight-Frank.pdf

18. Lim, L. C., McGreal, S., \& Webb, J. R. (2006). Perception of Real Estate Investment Opportunities in Central/South America and Africa. Journal of Real Estate Portfolio Management, 12(3), 261-276.

19. Newell, G., Wing, C. K., Kei, W. S., \& Hiang, L. K. (2009). The significance and performance of property securities markets in the Asian IFCs. Journal of Property Research, 26(2), 125-148. doi: 10.1080/09599910903441721

20. Ratcliffe, J. (2009). Urban Planning and Real Estate Development. London: Routledge. doi: 10.4324/9780203935729

21. The World Bank Africa Region. (2011 March). Africa's Future and the World Bank's support to It. Retrieved from http://siteresources.worldbank.org/INTAFRICA/Resources/AFR_Regional_Strategy_3-2-11.pdf

22. Transparency International. (2015). Corruption Perception Index 2014: Results. Retrieved March 1, 2019, from https://www.transparency.org/cpi2014/results

23. World Economic Forum. (2014). Global Competitiveness Report 2014-15. Retrieved from http://www3.weforum.org/docs/WEF_GlobalCompetitivenessReport_2014-15.pdf 